\title{
The impact of ambient temperature on mortality among the urban population in Skopje, Macedonia during the period 1996-2000 Vladimir T Kendrovski*
}

Address: Department for Hygiene and Environmental Health, Medical Faculty, University "St. Cyril and Methodius", 50 Divizija 6, Skopje, Republic of Macedonia

Email: Vladimir T Kendrovski* - kendro@mt.net.mk

* Corresponding author

Published: 23 February 2006

BMC Public Health 2006, 6:44 doi:10. I I86/ I47/-2458-6-44

This article is available from: http://www.biomedcentral.com/I47/-2458/6/44

(c) 2006 Kendrovski; licensee BioMed Central Ltd.

This is an Open Access article distributed under the terms of the Creative Commons Attribution License (http://creativecommons.org/licenses/by/2.0), which permits unrestricted use, distribution, and reproduction in any medium, provided the original work is properly cited.
Received: 10 August 2005

Accepted: 23 February 2006

\begin{abstract}
Background: This study assesses the relationship between daily numbers of deaths and variations in ambient temperature within the city of Skopje, R. Macedonia.

Methods: The daily number of deaths from all causes, during the period 1996-2000, as well as those deaths from cardiovascular diseases, occurring within the city of Skopje were related to the average daily temperature on the same day using Multiple Regression statistical analyses. Temperature was measured within the regression model as two complementary variables: 'Warm' and 'Cold'. Excess winter mortality was calculated as winter deaths (deaths occurring in December to March) minus the average of non-winter deaths (April to July of the current year and August to November of the previous year).

Results: In this study the average daily total of deaths was $7 \%$ and I $3 \%$ greater in the cold when compared to the whole period and warm period respectively. The same relationship was noticed for deaths caused by cardiovascular diseases. The Regression Beta Coefficient $(b=-0.19)$ for the total mortality as a function of the temperature in Skopje during the period 1996-2000 was statistically significant with negative connotation as was the circulatory mortality due to average temperature (statistically significant regression Beta coefficient $(b=-0.24)$ ). A measure of this increase is provided, on an annual basis, in the form of the excess winter mortality figure.
\end{abstract}

Conclusion: Mortality with in the city of Skopje displayed a marked seasonality, with peaks in the winter and relative troughs in the summer.

\section{Background}

All climate and weather variables have some influence on human health. The effect may be either directly on the human body or indirectly through effects on disease-causing organisms or their vectors. Although the effects of variation of only one weather element may be examined in a particular study, that element does not act independently of other elements, for example, changes in humidity mod- ify the effects of temperature. An association between cardiovascular deaths and outdoor temperature has been a topic of interest since 1970 [1-4]. It is generally agreed that as temperature decreases the risk of death increases. Increases in coronary events have also been seen during heat waves. Interactions between climate and health are location-specific; using epidemiological evidence based on local data if they are available is therefore important. It 
Table I: The design of the Study- distribution by variables

Study period: from 0I.0I.1996 to 3I.I2.2000 VARIABLE: TOTAL N(days) = 1827

VARIABLE: COLD MONTHS IN I 996-2000 (JANUARY, FEBRUARY, $M A R C H, A P R I L, N O V E M B E R, D E C E M B E R) \mathbf{N}($ days $)=907$
VARIABLE: WARM MONTHS IN 1996-2000 (MAY, JUNE, JULY, AUGUST, SEPTEMBER, OCTOMBER) $\mathbf{N}$ (days) $=\mathbf{9 2 0}$ is well-known that urban areas experience specialized problems relating to climate and human health [5]. For example, heat-related mortality is excessive in these areas, and pollution problems may exacerbate other conditions, such as asthma and respiratory distress. Recent studies in Europe and Russia show that mortality increases to a greater extent for a given fall in temperature in regions such as the UK and Greece that have relatively warm winters, than in colder countries where priority is given to keeping warm regardless of other factors. This was associated with cooler homes and wearing of less effective clothing outdoors in countries with mild winters [6-8].

Although Republic of Macedonia is relatively small country, its territory is covered by different types of climate: from continental, changed continental, sub-Mediterranean (changed maritime) to mountainous climate with various subtypes. Within the territory of the Republic of Macedonia the influences of the Mediterranean and the continent overlap, with different spectrum of influences. Macedonia has a basic Mediterranean climate of hot, dry summers; winters, however, are somewhat warmer than in northern neighboring countries due to the influence of the winds from the Aegean Sea. Average daily temperature extremes in Skopje range from $32^{\circ} \mathrm{C}$ to $-3^{\circ} \mathrm{C}$. The summers are warm, dry and long lasting; and the winters are cold, wet with foggy and snowy days [9].

The main goal of this study is to increase awareness about the impact of climatic on health in a densely populated area in Macedonia by relating mortality data to outside air temperature in the urban area of Skopje during the period 1996 to 2000.

\section{Methods}

The study was carried out in the city of Skopje, Republic of Macedonia. Its population, according to the census of
2002, is over 500.000 inhabitants. The epidemiological study is designed as retrospective research. The research material is presented as climatic data (the ambient air: daily average temperature) as well as mortality daily data for Skopje as urban area. Quantifying temperature-related mortality for Skopje requires access to daily mortality data as well as daily climatic (air temperature) data. The daily number of deaths in Skopje was obtained from the State Statistical Office, Mortality Register and was restricted to city residents only. The completeness of the register, the quality of patient diagnosis and certificated cause of death have been examined and it has been demonstrated that the register is both complete and reliable, i.e. more than $99 \%$ of deaths are confirmed by physicians. The causal groups considered in this study are total mortality and deaths from diseases of the circulatory system (ICD-9 codes 390-459). The mean daily temperature for Skopje (city's weather station) was obtained from the National Hydro-meteorological Institute.

The large number of days $(\mathrm{N}=1827)$ for the study period from 01.01 .1996 to 31.12 .2000 , i.e. the distribution of daily total deaths in Skopje, make possible the stratification of the sample in two variables ("warm" and "cold") in order to assess the effect of ambient temperature on mortality in different months without big fluctuation in temperature values. In each, analysis was carried out for the entire period of study and for two semestral periods. (Table 1) Specifically, it was decided to group the relatively colder months (October-April), and the hotter months (May-October). The historical long-term monthly temperature average data for Skopje showed that April is colder than October.

In this article we only present the results of the stratified analysis since this more reflects the dynamic relationship between temperature and mortality.

Table 2: The distribution of daily average mortality (total and specific mortality data) and temperature in Skopje for the period I9962000 by variables

\begin{tabular}{lcccccccc}
\hline & \multicolumn{3}{c}{ TOTAL (1996-2000) } & & WARM MONTHS COLD MONTHS \\
\cline { 2 - 8 } & $\bar{X}$ & SD & min. & & $\bar{X}$ & SD & $\bar{X}$ & SD \\
\hline Total mortality & 10,01 & 3,45 & 1,00 & 24,00 & 9,33 & 3,25 & 10,69 & 3,52 \\
Mortality from circulatory diseases & 5,38 & 2,46 & 1,00 & 17,00 & 4,85 & 2,26 & 5,91 & 2,53 \\
Temperature $\left({ }^{\circ} \mathrm{C}\right)$ & 12,80 & 9,08 & $-11,40$ & 31,40 & 20,02 & 5,42 & 5,41 & 5,42 \\
\hline
\end{tabular}




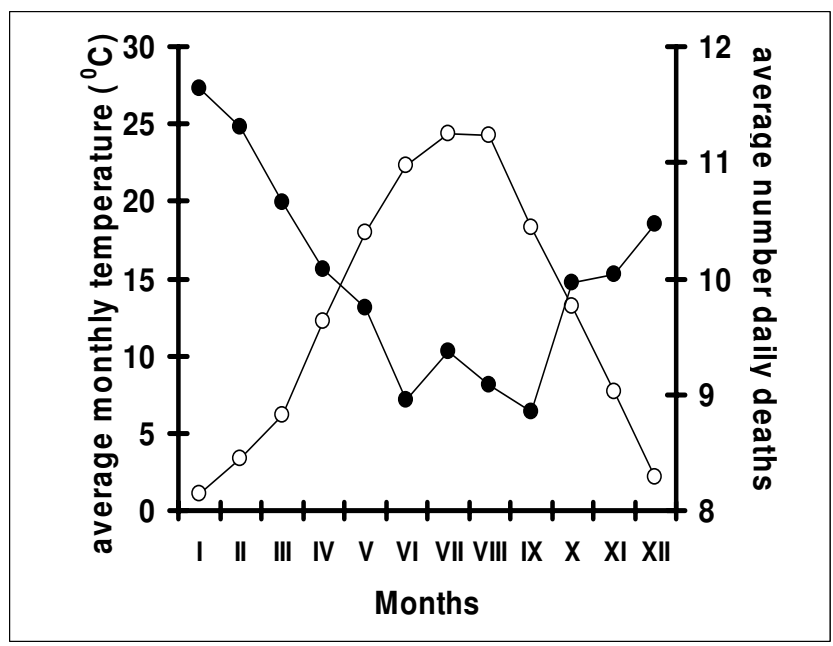

\section{Figure I}

The distribution of average daily number of deaths from all causes for the period 1996-2000 in Skopje by months.

The daily number of deaths from all causes, during the period 1996-2000, as well as those deaths from cardiovascular diseases, occurring within the city of Skopje were related to the average daily temperature on same day using Multiple Regression statistical analyses. Temperature was measured within the regression model as two complementary variables: 'Warm' and 'Cold'. Scatter charts for mortality residuals data were produced for total deaths and temperature for all variables

Excess winter mortality is calculated as winter deaths (deaths occurring in December to March) minus the average of non-winter deaths (April to July of the current year and August to November of the previous year) [10].

\section{Results}

The mean daily number of deaths among the citizens of the city of Skopje for 1996-2000 were 10.01 with a standard deviation of 3.45. (Table 2)

In this study average daily total of deaths was $7 \%$ and $13 \%$ greater in the cold when compared to the whole period and warm period respectively. The same relation was noticed for deaths caused by cardiovascular diseases.

Also we noticed that January, February, March and December were months with greater daily mortality among the citizens of Skopje for the estimated period when compared to the summer months: September, June, August and July. (Figure 1)

From a graphical analysis of the whole period, a relationship between the average daily deaths from all causes and average monthly temperature appears graphically as a polynomial quadratic equation (Figure 2).

The warmest month was July with average monthly temperature of $24,34^{\circ} \mathrm{C}$ and January was the coldest month with $1,1^{\circ} \mathrm{C}$ average monthly temperature, retrospectively. The January value is $16.3 \%$ greater than the yearly average daily number of deaths (10.01), and the September value $11.6 \%$ below the yearly average. The difference between January and September is $27.9 \%$. (from +16.3 to -11.6 )

The nature of the relationship between temperature and mortality was also analysed by season consistent with those presented here. The Regression Beta Coefficient $(\mathrm{b}=$ -0.19) for the total mortality as function of the temperature in Skopje during the period 1996-2000 as well as was for the daily average mortality from diseases of the circulatory system $(b=-0.24)$ were statistically significant with negative connotation.

Mortality within the city of Skopje displayed a marked seasonality, with peaks in the winter and relative troughs in the summer.

From a graphical analysis of the whole period, a relationship between the number of daily deaths from all causes and mean daily temperature appears graphically as a nonmonometric ' $U$ ' shape - the lowest mortality rate being reached at temperatures within a range between $17-23^{\circ} \mathrm{C}$. (Figure 3)

Taking the two periods separately, it can be seen that, as well as a seasonal effect (i.e. more deaths occurring during

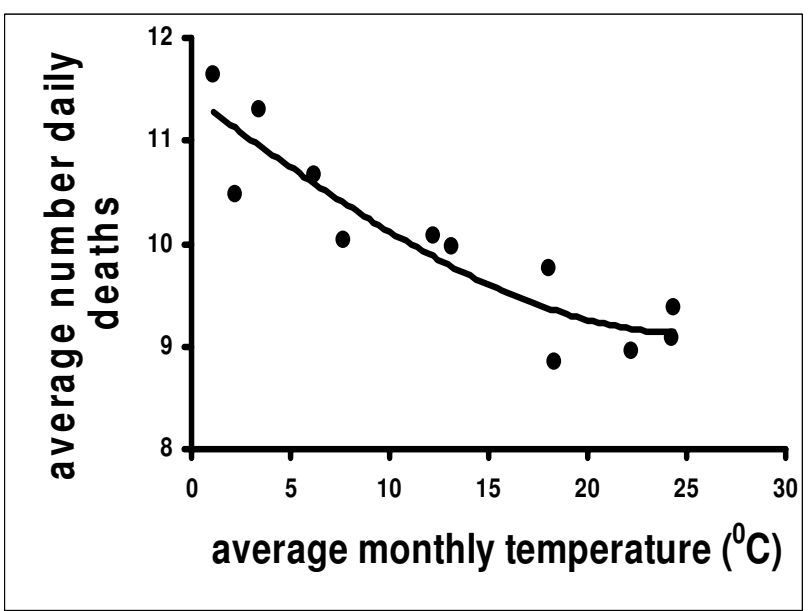

Figure 2

The relationship between average daily number deaths from all causes and average monthly temperature for the period 1996-2000. 


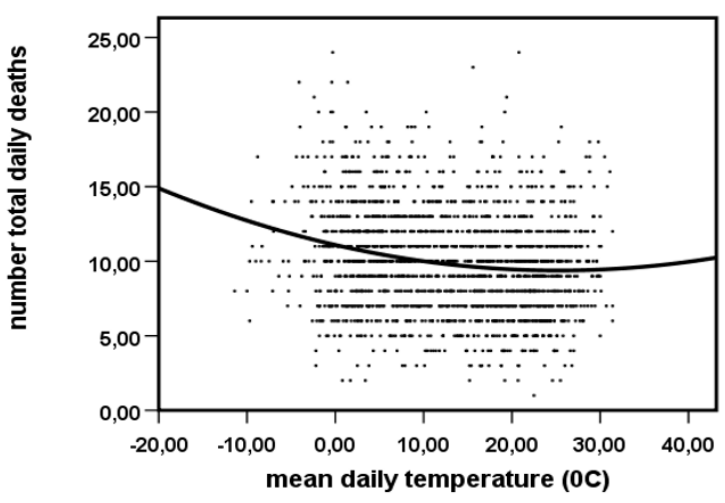

Figure 3

Scatter diagram for all cause daily mortality and mean daily temperature, Skopje, 1996-2000.

the 'cold' months than in the 'warm' months), the affect of temperature on all cause daily mortality rate is much clearer when mortality rate is related to either the 6 coldest or the 6 warmest months of the year (Figure 3 and Figure 4) rather than to the whole year.

The mortality minima can be found within a wide temperature range centred around $14^{\circ} \mathrm{C}$ during the colder months and around $21^{\circ} \mathrm{C}$ during the hotter month. In order to assess mortality levels over the winter as a whole we estimated the excess winter mortality for four winters in the period 1996-2000 for Skopje. (Table 3)

The results show that winter mortality varied from winter to winter, being highest in the winter of $1999 / 2000$, accounting for $47 \%$ of all excess deaths of the combined four winters examined.

\section{Discussion}

In this study, the air temperature at which all cause mortality reached its minimum was around $18^{\circ} \mathrm{C}$. This value is lower to that found in other studies carried out in lower zones with latitudes and climate similar to Skopje e.g. Valencia, Athens and Barcelona with around $24^{\circ} \mathrm{C}$ [1113]. Nevertheless, in other areas this minimum is located around manifestly different temperatures. In a subtropical country such as Taiwan it is situated around $26-29^{\circ} \mathrm{C}$ whereas in a country such as Holland, with its colder and more humid climate, it is around $16.5^{\circ} \mathrm{C}[14,15]$. Two hypotheses have been advanced to explain these differences: on the one hand, they could reflect differences in housing conditions (insulation, heating etc.) or differences in lifestyle patterns, with people living in warmer countries spending longer outdoors. On the other hand, it could also correspond to an acclimatization process to the variations in temperature. Respiratory infections may be responsible for deaths whose basic cause has been classified as cardiovascular. An indirect mechanism which may help to account for this process would be the increase in platelet aggregation during infections $[15,16]$.

In this study average daily of total deaths is $7 \%$ and $13 \%$ greater in the cold months compared to the whole period and hot period respectively. The size of the increased risk attributable to cold temperatures seems to depend on the average annual temperature; for example, the Eurowinter group found smaller increases in cardiovascular mortality in colder regions (Finland) than in warmer regions [4]. Increased mortality from coronary thrombosis in the cold is associated with haemoconcentration (thickening of the blood), which occurs as fluid is lost from the circulation after vasoconstriction in the cold, and with increased blood pressure and with raised fibrinogen levels due to respiratory infections in winter. Arterial thrombosis due to these changes causes just over half of the excess winter deaths, and respiratory disease approximately a further $20 \%$. A hypothesised pathway for the increased risk of coronary events in colder periods is that exposure to cold temperatures triggers rapid release of cathecholamines with consequent rises in vasomotor tone, haemodynamic parameters, platelet aggregability, and other haemathological and endothelial parameters [17]. When a person comes from warm indoor to cold conditions, the subsequent increase in cardiac workload and oxygen consumption may trigger an acute coronary syndrome [18-22].

Table 3: The excess winter mortality in Skopje during the period 1996-2000

\begin{tabular}{|c|c|c|c|c|c|c|}
\hline \multirow[b]{2}{*}{ Winter } & \multicolumn{3}{|c|}{ Excess winter mortality in absolute numbers } & \multicolumn{3}{|c|}{ Index of Excess winter mortality in \% } \\
\hline & Males & Females & Total & Males & Females & Total \\
\hline 1996//997 & 110,5 & 89 & 199,5 & 18 & 18 & 18 \\
\hline $1997 / 1998$ & 12 & 58,5 & 70,5 & $\mathbf{I}$ & 11 & 6 \\
\hline $1998 / 1999$ & 45 & 69 & 114 & 6,6 & 13,1 & 9,5 \\
\hline $1999 / 2000$ & 130,5 & 213,5 & 344 & 19,7 & 44,1 & 30 \\
\hline Total & 298 & 430 & 728 & 11.3 & 21.5 & 15,9 \\
\hline
\end{tabular}




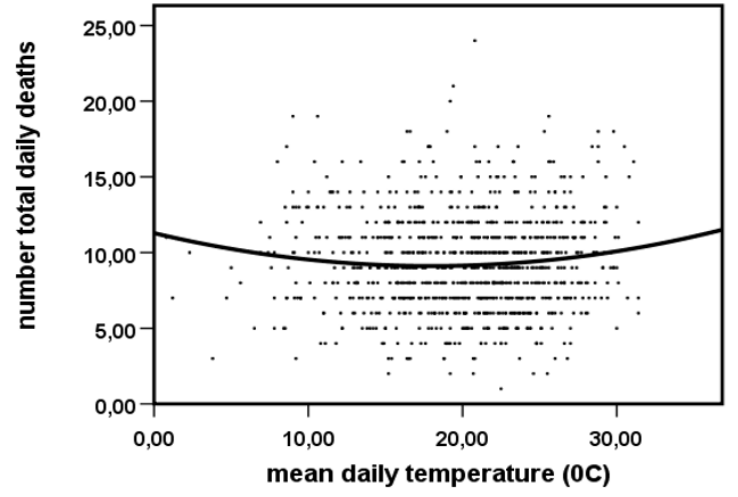

\section{Figure 4}

Scatter diagram for all cause daily mortality and mean daily temperature, Skopje, warm months, 1996-2000.

Excess winter mortality has been reported in medical journals for about 150 years, and most countries suffer from $5 \%$ to $30 \%$ excess winter mortality [23]. However, there still remains much debate with regard to why certain countries experience dramatically higher rates of seasonal mortality than others. In this study the winter of 1999/ 2000 , accounting for $47 \%$ of all excess deaths of the combined four winters examined. We need additional investigation to discuss what was unique in this winter to account for 2,5 times the expected number of deaths $(47 \%)$. Cold strain from both indoors and outdoors has been implicated on several occasions, however other

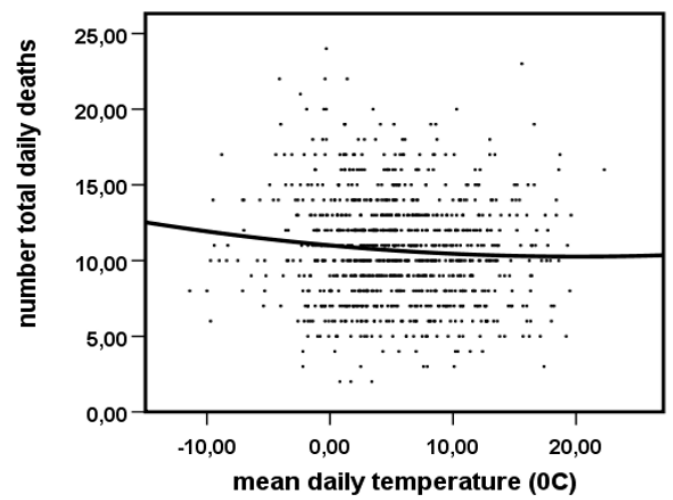

Figure 5

Scatter diagram for all cause daily mortality and mean daily temperature, Skopje, cold months, 1996-2000. potential factors (other than cold strain) have rarely been analysed. Besides factors associated with biological and genetic considerations that have been linked with reduced health status, the health of a population is influenced by a large number of factors. In this study women showed greater winter mortality in cold periods compared with men. However, there are also physiological sex differences in thermoregulation, including longer recovery time to body temperature after physical exercise among women, which could partly mediate the increased risks in women [24].

\section{Conclusion}

There are a number of limitations due mainly to the ecological design of the study. Another weakness is that we did not control for air pollution, and increases in air pollution have been shown to correlate with the risk of a cardiovascular event, and the seasonal change in risk. Also we were not able to control for respiratory infections, which are common in cold and damp conditions and may precipitate a coronary event.

In this study it has been shown that mortality rates in the urban area of Skopje are increased during the winter months. It is suggested that the excess is preventable and is most probably attributable to poor protective measures taken on cold days or other related factors. It is concluded that efforts should be made to make the general public more aware about the phenomena of excess winter mortality, particularly in Macedonia.

\section{Competing interests}

The author(s) declare that they have no competing interests.

\section{Acknowledgements}

This study was made possible thanks to a support from Blagoja Aleksoski, the Director of the Republic Institute for Health Protection, Skopje and a stimulating working environment at this Institute.

\section{References}

I. Anderson TW, Le Riche WH: Cold weather and myocardial infarction. Lancet 1970, 295:29|-6.

2. Rogot E, Padgett SJ: Associations of coronary and stroke mortality with temperature and snowfall in selected areas of United States, 1962-1966. Am J Epidemiol 1976, 103:565-75.

3. Kunst $A E$, Groenhof $F$, Mackenbach JP: The association between two windchill indices and daily mortality variation in the Netherlands. Am J Public Health 1994, 84: $1738-42$.

4. The Eurowinter Group: Cold exposure and winter mortality from ischaemic heart disease, cerebrovascular disease, respiratory disease, and all causes in warm and cold regions of Europe. Lancet 1997, 349:134I-6.

5. Barnett GA, J Dobson JA, McElduff P, Salomaa V, Kuulasmaa K, Sans $S$ : Cold periods and coronary events: an analysis of populations worldwide. Journal of Epidemiology and Community Health 2005, 59:55I-557.

6. Keatinge WR, Donaldson GC, Bucher K, Cordioli E, Dardanoni L, Jendritzky G, Katsouyanni K, Kunst AE, Mackenbach JP, Martinelli M, McDonald C, Nyh S, Vuori I: Cold exposure and winter mortality from ischaemic heart disease, cerebrovascular disease, 
respiratory disease, and all causes in warm and cold regions of Europe. Lancet 1997, 349:134 I-I346.

7. Donaldson GC, Ermakov SP, Komarov YM, McDonald CP, Keatinge WR: Cold-related mortalities and protection against cold in Yakutsk, Eastern Siberia: observation and interview study. BMJ 1998, 3 I 7:978-82.

8. Donaldson GC, Tchernjavskii VE, Ermakov SP, Bucher K, Keatinge WR: Effective protection against moderate cold, with rise in mortality only below $0^{\circ} \mathrm{C}$, in Yekaterinburg, Russian Federation. BMJ 1998, 316:514-518.

9. Kendrovski V, Gjorgjev D, Ristevski P: Climate change and human health in the Republic of Macedonia-needs for action. JEPE 2003, 4(4):987-992.

10. Office for National Statistics: Methodology for calculating provisional excess winter mortality London 2002.

II. Ballester F, Corella D, Perez-Hoyos S, Saez M, Hervas A: Mortality as a function of temperature. A study in Valencia, Spain, | 99|-| 993. Int J Epidemiol | 997, 26:55|-6I.

12. Touloumi G, Pocock SJ, Katsouyanni K, Trichopoulos D: Shortterm effects of air pollution on daily mortality in Athens: $A$ time series analysis. Int J Epidemiol 1994, 23:957-67.

13. Saez M, Sunyer J, Castellsague J, Murillo C, Anto JM: Relationship between weather temperature and mortality: a time series analysis approach in Barcelona. Int J Epidemiol 1995, 24:576-82.

14. Pan WH, Li LA, Tsai MJ: Temperature extremes and mortality from coronary heart disease and cerebral infarction in elderly Chinese. Lancet 1995, 345:353-55.

15. Kunst AE, Looman CW, Mackenbach JP: Outdoor air temperature and mortality in the Netherlands: a time series analysis. American Journal of Epidemiology 1993, 137:331-34I.

16. Woodhouse PR, Khaw KT, Plummer M, Foley A, Meade TW: Seasonal variations of plasma fibrinogen and factor VII activity in the elderly: winter infections and death from cardiovascular disease. Lancet 1994, 343:435-439.

17. Mercer JB, Osterud B, Tveita T: The effect of short-term mild cold exposure on risk factors for cardiovascular disease. Thrombosis Research 1999, 95:93-104.

18. Keatinge WR, Coleshaw SRK, Holmes J: Changes in seasonal mortalities with improvement in home heating in England and Wales from 1964 to 1984. Int J Biometeorol 1989, 33:71-76.

19. Donaldson GC, Keatinge WR: Early increases in ischaemic heart disease mortality dissociated from, and later changes associated with, respiratory mortality, cold weather in south east England. J Epidemiol Community Health 1997, 5 I:643-648.

20. Neild PJ, Syndercombe Court D, Keatinge WR, Donaldson GC, Mattock $M$, Caunce $M$ : Cold-induced increases in erythrocyte count plasma cholesterol and plasma fibrinogen of elderly people without a comparable rise in Protein-C and FactorX. Clin Sci 1994, 86:43-48.

21. Woodhouse PR, Khaw KT, Plummer M: Seasonal variation of blood pressure and its relationship to ambient temperature in an elderly population. J Hypertension I993, I I:I 267-I274.

22. Wilkinson P, Landon M, Armstrong B, Stevenson S, McKee M: Cold comfort: the social and environmental determinants of excess winter death in England, 1986-1996. York: Joseph Rowntree Foundation; 200I.

23. Wilkinson P, Pattenden S, Armstrong B, Fletcher A, Kovats RS, Mangtani $P$, McMichael AJ: Vulnerability to winter mortality in elderly people in Britain:population based study. BMJ 2004, 329:647.

24. Healy JD: Excess winter mortality in Europe: a cross country analysis identifying key risk factors. Journal of Epidemiology and Community Health 2003, 57:784-789.

\section{Pre-publication history}

The pre-publication history for this paper can be accessed here:

http://www.biomedcentral.com/1471-2458/6/44/prepub
Publish with Biomed Central and every scientist can read your work free of charge

"BioMed Central will be the most significant development for disseminating the results of biomedical research in our lifetime. "

Sir Paul Nurse, Cancer Research UK

Your research papers will be:

- available free of charge to the entire biomedical community

- peer reviewed and published immediately upon acceptance

- cited in PubMed and archived on PubMed Central

- yours - you keep the copyright

Submit your manuscript here:

http://www.biomedcentral.com/info/publishing_adv.asp
BioMedcentral 